\title{
Expression analysis of genes involved in the synthesis of oleic and linoleic acids in Jatropha cinerea seeds from Northwestern Mexico
}

\author{
Jose Pablo Lovio-Fragoso ${ }^{1} \odot$ Luis Angel Medina-Juárez ${ }^{1} \odot$ Nohemi Gamez-Meza $^{1}$

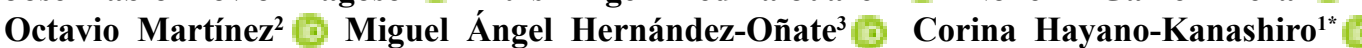

'Departamento de Investigaciones Científicas y Tecnológicas, Universidad de Sonora, Blvd. Luis Encinas y Rosales s/n. Colonia Centro, C.P. 83000, Hermosillo, Sonora, México. E-mail: angela.hayano@unison.mx. "Corresponding Author.

${ }^{2}$ Unidad de Genómica Avanzada (LANGEBIO-CINVESTAV, Irapuato). Km 9.6 Libramiento Norte Carretera León, C.P. 36821, Irapuato, Guanajuato, México.

${ }^{3}$ CONACYT-Centro de Investigación en Alimentación y Desarrollo, A.C. Carretera a La Victoria Km 0.6, C.P. 83304, Hermosillo, Sonora, México.

\begin{abstract}
Plants belonging to genus Jatropha has arisen interest because of its high oil content that could be used to produce biodiesel. It is also widely reported that the main fatty acids in Jatropha oilseed are oleic and linoleic acids. However, there are scarce studies related to native species of Jatropha from Northwestern Mexico which are adapted to arid conditions, and the expression of genes involved in fatty acid synthesis for these species is still unknown. Therefore, the aim of this study was to analyze the expression of five genes, ACP1, KASII, D9SD, FAD2-1 and FAD2-2, which are involved in the oleic and linoleic acids synthesis in mature wild-seeds of Jatropha cinerea, a native species from Sonoran Desert, using semi-quantitative RT-PCR. The J. cinerea seeds were randomly collected in Bahía de Kino, Sonora (México) which is a region characterized by its harsh environments such as saline soils and extreme temperature changes and J. curcas mature seeds from a non-toxic variety from Veracruz, Mexico were used as a reference. The RT-PCR analysis of three biological replicates were considered to ensure data consistent. Our analysis showed a higher expression of KASII and FAD2-1 genes in J. cinerea seeds compared to J. curcas, meanwhile the expression of ACP1, D9SD and FAD2-2 were higher in J. curcas. Furthermore, Actin and FAD2-1 genes sequences here obtained are the first reported for J. cinerea, thus providing information to develop further studies. Key words: fatty acids biosynthesis, PCR, KASII, FAD2-1.
\end{abstract}

Análise de expressão de genes envolvidos na síntese de ácidos oleico e linoleico em sementes de Jatropha cinerea do noroeste do México

RESUMO: Plantas pertencentes ao gênero Jatropha têm despertado interesse devido ao seu alto teor de óleo que poderia ser usado para produzir biodiesel. Também é amplamente relatado que os principais ácidos graxos das oleaginosas da Jatropha são os ácidos oléico e linoleico. No entanto, existem poucos estudos relacionados a espécies nativas de pinhão-manso do noroeste do México que estão adaptados a condições áridas, e a expressão de genes envolvidos na síntese de ácidos graxos para essas espécies ainda é desconhecida. Portanto, o objetivo deste estudo foi analisar a expressão de cinco genes, ACP1, KASII, D9SD, FAD2-1 e FAD2-2, que estão envolvidos na síntese de ácidos oleico e linoleico em sementes selvagens maduras de Jatropha cinerea, espécies nativas do Deserto de Sonora, usando RT-PCR semi-quantitativa. Sementes de J. cinerea foram coletadas aleatoriamente em Bahía de Kino, Sonora (México), região caracterizada por ambientes agressivos como solos salinos e mudanças extremas de temperatura, e sementes de J. curcas maduras de uma variedade não-tóxica de Veracruz, México, usado como referência. Análise RT-PCR de três repetições biológicas foram consideradas para garantir dados consistentes. Nossa análise mostrou uma maior expressão dos genes KASII e FAD2-1 em sementes de J. cinerea comparado a J. curcas, enquanto a expressão de ACP1, D9SD e FAD2-2 foi maior em J. curcas. Além disso, as sequências dos genes Actin e FAD2-1 obtidas são as primeiras relatadas para J. cinerea, fornecendo, assim, informações para o desenvolvimento de novos estudos.

Palavras-chave: Biossintese de ácidos graxos, PCR, KASII, FAD2-1.

\section{INTRODUCTION}

The genus Jatropha belongs to the Euphorbiaceae family and the plants of this genus are widely distributed around the world with approximately 186 species (FRESNEDORAMÍREZ \& OROZCO-RAMÍREZ, 2013).
Jatropha species are succulents, shrubs and trees that are well known by deep roots, allowing them to adapt to arid conditions. Moreover, Jatropha plants are distinguished by their ability to survive in dry and saline soils and conditions considered marginal for agriculture; their presence in these environments benefits the soil health; providing an organic mulch 
making the soil available for agricultural practices (BRITTAINE \& LUTALADIO, 2010). The study of Jatropha plants has being motivated by its potential as ornamentals, medical applications and oil extraction from various species for the production of paints and solvents and recently as an input for the production of biodiesel, since it has been reported that the most abundant fatty acids which are present in its oil are oleic and linoleic acids (MARTINEZ-HERRERA et al., 2010 WANG et al., 2011; GÁMEZ-MEZA et al., 2013; KHALIL et al., 2013). To obtain high quality biodiesel in terms of stability, oil must have a higher oleic acid content than linoleic acid content because it is known that a higher polyunsaturated fatty acids (PUFAs) content will impact negatively not only in the stability of the oil but also in the number of cetane which, is an important parameter considered in biodiesel production (YE et al.,2013).

Jatropha curcas is the most studied species among the genus. However, recent studies have been published on wild native species from Northwestern Mexico (J. cordata, J. cardiophylla, $J$. cuneata and $J$. cinerea); which are considered an imprint source of oilseed (30-40\% oil seed content), from which $30-50 \%$ consist in PUFAs (mainly linoleic acid). Therefore, studies using molecular markers based on its biochemical characteristics are done to improve the oil quality, developing new and non-toxic varieties and optimize the performance of the seeds (QU et al., 2012; OLIVEIRA et al., 2013). In Mexico, there are 48 species of Jatropha, of which 39 are endemic, representing $21 \%$ of all known species. Among the most representative species in arid regions and dry hot climates in the Northwestern Mexico are included J. cordata, J. cardiophylla, J. malacophylla, J. cuneata and J. cinerea (FRESNEDO-RAMÍREZ \& OROZCORAMÍREZ, 2013).

Jatropha cinerea, a wild species relative close to Jatropha curcas (the most representative of the genus), is widely distributed along the coast of Sonora, the Baja California Peninsula and Sinaloa (TURNER et al. 2005). It grows in saline soils and is adapted to dry and subtropical climates and often exposed to long drought periods (HISHIDA et al., 2014). Besides, Jatropha cinerea mature seeds have an important oil content composed mainly by oleic and linoleic acid (SOSA-SEGURA et al., 2014; SOTO-LEÓN et al., 2014; LOVIO-FRAGOSO, et al., 2017). This information suggests that Jatropha cinerea may be an appropriate species for studying as a biofuel source for its abundant seed production under harsh conditions, factors that limit the Jatropha curcas development in regions as the Sonoran Desert with temperatures around $45^{\circ} \mathrm{C}$ and scarce annual precipitation (HISHIDA et al., 2014). Conversely, the information related to genes involved in fatty acid synthesis in these species is limited. Therefore, the aim of this study was to analyze the level expression of genes involved in the synthesis of the oleic and linoleic acids in J. cinerea and $J$. curcas mature seeds and correlate the amount of these oils in the seeds.

\section{MATERIALS AND METHODS}

\section{Plant material}

Jatropha cinerea mature wild-seeds were randomly collected on October 2014 in Bahía de Kino, Sonora, México (2849' 52.1106' N $111^{\circ} 44^{\prime}$ ' 23.316" O and 28 49'45.6234" N 111 ${ }^{\circ} 57^{\prime}$ ' 12.1176" O). Jatropha curcas mature seeds from a nontoxic variety from Veracruz, Mexico were used as a reference. Seeds were manually shelled and dried under sun for $12 \mathrm{~h}$ and stored in plastic containers at $-80^{\circ} \mathrm{C}$ prior to analysis.

\section{Total RNA isolation and purification}

Total RNA was isolated from ground seeds using TRIZOL (Invitrogen, Whaltman, United States of America) according to the manufacturer's protocol. The RNA samples were purified using RNEasy MinElute Cleanup Kit (Qiagen, Venlo, Netherlands) following the manufacturer's protocol. Then, total RNA was quantified with spectrophotometry using a NanoDrop 1000 (Thermo Scientific, Wilmington, United States of America) and the purity was assessed using the 260/280nm and 260/230nm absorbance ratios. Afterwards, the integrity of the RNA samples was determined by $1.0 \%$ agarose gel electrophoresis and GelRed ${ }^{\mathrm{TM}}$ (Biotium, Fremont, United States of America).

\section{cDNA synthesis}

For semiquantitative RT-PCR, the cDNA was obtained from $2 \mu \mathrm{g}$ of total RNA by reverse transcription using SuperScript ${ }^{\mathrm{TM}}$ III Reverse Transcriptase kit (Invitrogen, Whaltman, United States of America) and the Ilustra ReadyTo-Go RT-PCR Beads kit (General Electric, Chicago, United States of America) according to the manufacturer's protocol; a DNase I 
(Roche, Mannheim, Germany) treatment step was included prior cDNA synthesis. In the absence of information on $J$. cinerea sequences, primers sequences used were taken from existing information in J. curcas genome. The Jatropha curcas Actin gene was used as an internal control.

Semiquantitative RT-PCR was performed using the Illustra ${ }^{\mathrm{TM}}$ PuReTaq $^{\mathrm{TM}}$ Ready-To-Go ${ }^{\mathrm{TM}}$ PCR beads kit (General Electric, Chicago, United States of America) following the manufacturer's instructions. The reaction was carried out in a SimpliAmp ${ }^{\mathrm{TM}}$ thermocycler (Applied Biosystems, Foster, United States of America). Amplified products were analyzed by electrophoresis on $1.0 \%$ gels containing GelRed ${ }^{\mathrm{TM}}$ (Biotium, Fremont, United States of America) and visualized with a transilluminator Bio-Imaging System MiniBis pro (Bio America Inc, Miami, United States of America). Relative intensities of the amplified PCR products were determined using Image $\mathbf{J}$ (Java) an image analysis software (version 1.7.0 51) and expressed in arbitrary units (AU). The ratio between the RNA sample to be determined and Actin was calculated to normalize for initial variations in sample concentration and as an efficient reaction control. Three biological replicates were performed for both species to ensure consistent data which was expressed as the average of fold-difference of expression levels.

\section{Sequencing analysis}

The gDNA (genomic DNA) was extracted from Jatropha cinerea leaves that were collected during the seed collection and stored at $-80^{\circ} \mathrm{C}$ prior to use. The gDNA extraction was performed using the Plant ZR/Seed Zymo Research Miniprep DNA kit (Zymo Research, Irvine, United States of America) following the manufacturer's instructions. Resulting gDNA was used to perform PCR reactions of each gene considered in this study. $100 \mu \mathrm{l}$ of PCR products amplified from gDNA of Jatropha cinerea were obtained for each gene and sent to Laboratorio de Servicios Genómicos, LANGEBIO CINVESTAV (Irapuato, Mexico) for analysis. Resulting sequences were analyzed using the program BioEdit version 7.2.5 (Hall, Ibis Biosciences, CA, USA) and used BLAST for comparison to the correspondence Jatropha sequences.

\section{RESULTS AND DISCUSSION}

\section{$R T-P C R$}

Genes involved in the oleic acid synthesis

ACP enzymes are cofactors responsible for acyl chain modification and chain-length termination during lipid biosynthesis in living organisms, being the isoform I the one that is reported mainly in seeds (LI et al., 2010). The ACP1 gene analysis showed that this gene had a lower expression in mature seeds of $J$. cinerea (0.22-fold) compare with J. curcas (0.57-fold) (Figure 1). The LI et al. (2010) measured the ACP mRNA levels in developing peanut seeds, finding that at initial stages of seed development the levels of poly (A) mRNA per seed increased sharply and then decreased steadily as the seed matured. This coincides with the reported by GU et al. (2012), that during Jatropha curcas seeds development, the expression of this gene increases progressively as an indicator of fatty acids synthesis to cover its physiological needs; once the seeds reach maturity, this gene is practically downregulated.

The synthesis of fatty acids in plants occurs mainly in plastids by the condensation of malonyl-CoA by KAS enzymes, of which isoform II is responsible for final elongation step in the form of plastids $\mathrm{C} 16: 0$ ACP to $\mathrm{C} 18: 0 \mathrm{ACP}$ (MA et al., 2017). It has been reported that at mature stages of development of Jatropha curcas seeds, the expression of KASII gene tends to be highly induced (GU et al., 2012); once the fatty acid is elongated from $\mathrm{C} 16$ to $\mathrm{C} 18$, it can subsequently undergo desaturation for obtaining unsaturated fatty acids (WEI et al. 2012). In the present study, the expression analysis showed a higher induction of KASII gene from Jatropha cinerea of 0.80-fold than Jatropha curcas seeds 0.66-fold (Figure 1), suggesting that in Jatropha cinerea could be a mechanism that favors the elongation from $\mathrm{C} 16: 0$ to C18:0 over Jatropha curcas but it is necessary to develop further studies to confirm this statement.

The $D 9 S D$ gene is linked to the synthesis of oleic acid; according to the analysis performed in this study, D9SD was defined as a low expression gene. The D9SD expression analysis in Jatropha cinerea seeds showed no expression of this gene while in Jatropha curcas seeds this gene was expressed 0.72fold higher (Figure 1). GU et al. (2012) reported that at mature stages of the development of $J$. curcas seeds, D9SD is downregulated. Moreover, it has been reported in Jatropha curcas that at filling stages of the seed's development, D9SD gene showed high expression and then it decreased abruptly as the seeds approach maturation (GU et al., 2012). These results suggested that at mature stages the oleic acid synthesis in Jatropha cinerea seeds is reduced or practically repressed. In spite of a high content of oleic acid, in both species, a slight relationship 


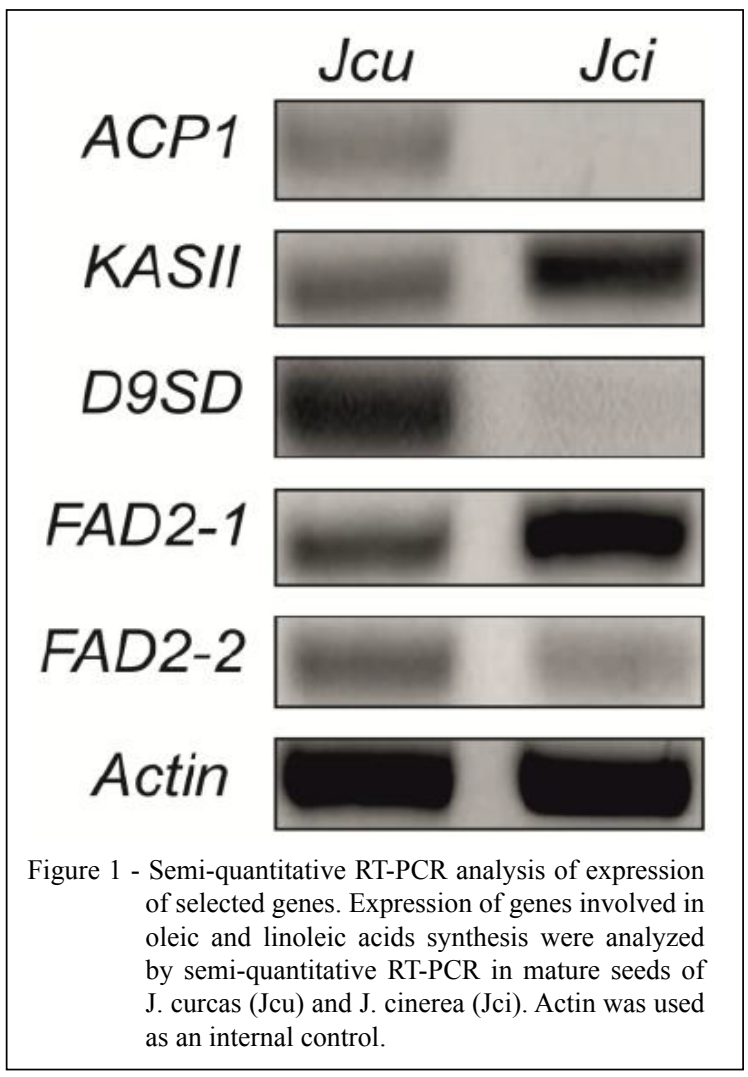

was showed between the gene expression and its content for $J$. curcas (37.59g / 100g FAME) and for $J$. cinerea (34g / 100g FAME) according to LOVIOFRAGOSO et al. (2017).

Genes involved in the linoleic acid synthesis

The FAD2 gene family which encode the enzymes 1-acyl-2-oleoyl-sn-glycero-3phosphocholine delta 12-desaturases (FAD2) are responsible for the production of linoleic acid from oleic acid in oilseeds plants. Whereas Arabidopsis thaliana has a single FAD2 gene that is expressed in seed and vegetative tissues, in J. curcas, three putative genes have been identified that encoded to FAD2 proteins (JcFAD2-1, JcFAD2-2 and JcFAD2$2 m$ ) (QU et al. 2012). The FAD2-1 gene is high expressed in seeds compared to other tissues, while FAD2-2 is high expressed in seeds and not detectable in leaves (TANG et al. 2005); even though FAD22 also contributes in the production of linoleic acid; however, FAD2-1 (JcFAD2-1) gene has been of particular interest because it is considered the main gene responsible for the conversion of oleic acid to linoleic acid and because it has been reported that its expression level is higher than that of FAD2-2 during the period of maximal storage lipids biosynthesis of seed development (QU et al., 2012). In this context, our analysis showed that in Jatropha cinerea seeds the FAD2-1 gene had a higher expression (0.66-fold) than Jatropha curcas seeds 0.51-fold (Figure 1). Instead, the FAD2-2 gene showed a lower expression in Jatropha cinerea seeds (0.27-fold) while in Jatropha curcas seeds this gene showed a higher expression (0.66-fold, Figure 1). In addition, linoleic acid content differs slightly between $J$. cinerea (46.92g / 100g FAME) and $J$. curcas $(42.81 \mathrm{~g} / 100 \mathrm{~g}$ FAME) (LOVIOFRAGOSO, et al., 2017). These results showed a moderate relationship between linoleic acid content and the expression of FAD2 genes, suggesting that the linoleic acid production is slightly favored in mature seeds of $J$. cinerea compared than $J$. curcas seeds, and FAD2-1 is the main gene responsible of the linoleic acid synthesis. According to the study performed by GU et al. (2012), desaturases play a crucial role as responsible for the presence of polyunsaturated fatty acids. It has been reported in other studies that the FAD2 transcript expression differed significantly from D9SD expression pattern. The FAD2 expression increased sharply at the first stages of seed development and reaching levels that surpass anthesis and slowly decreases as seeds approach to maturation, agreeing to reports of GU et al. (2012) with RUUSKA et al. (2002) results in Arabidopsis and FOFANA et al. (2006) in flax, in which a bell-shaped pattern was also observed in FAD2 expression. Moreover, it is important to mention that FAD2 genes are related to environmental adaptation of plant vegetative growth and it is also reported its expression as response to abiotic stress, being evaluated its expression as consequence of the production of linoleic acid under low temperatures and its necessary presence under salt stress showing an increased at its expression levels in Arabidopsis (SCHERDER \& FEHR, 2008; ZHANG et al. 2012). This suggested that FAD2-1 expression in Jatropha cinerea seeds could also be related to salinity tolerance because it is growing in saline soils.

Conversely, there are other genes involved in the oleic and linoleic acid synthesis that are not considered in this study that could provide more information to comprehend the relationship between the levels of expression of the genes and the presence of fatty acids, specifically oleic and linoleic acids. The study of 
these and other genes involved in the biosynthesis of fatty acids could provide a more complete insight between expression and content in seeds. Moreover, there are other factors that could have influenced in our results as the design of primers used in PCR reactions based on Jatropha curcas genome due to the absence of $J$. cinerea sequences in databases; therefore, it could affect the results when comparing gene expression along with the fatty acid profile (HERNÁNDEZ et al., 1994). It is worth to mention that this is the first study that analyzes the oleic and linoleic acid genes in Jatropha cinerea seeds and give valuable information to understand the relationship between the levels of expression of the genes and the presence of fatty acids as well as the suggestion to use this species as an alternative source for biofuel production in arid regions.

\section{Sequencing analysis}

PCR products from Actin, $A C P 1, K A S I I$, D9SD, FAD2-1 and FAD2-2 genes of Jatropha cinerea were sequenced from gDNA to obtain the greatest coverage of these genes and thus get more information of each one as possible. Sequences were analyzed and compared in public databases such as GenBank, using the National Center for Biotechnology Information (NCBI) with the Basic Local Alignment Search Tool (BLAST), considering parameters as identity percentage, e-value $(<1 \mathrm{e}-03)$ and sequence number to confirm if they correspond to the genus Jatropha and the specific gene examined. As we expected, our results showed a high identity of the Jatropha cinerea sequences with the Jatropha curcas sequences deposited in the GenBank (Table 1), suggesting a close phylogenetic relationship between both species.

Results generated in the present study provided highly relevant information because to our knowledge, this is the first report on analyzing the expression of genes involved in the oleic and linoleic acid synthesis in $J$. cinerea. Moreover, here we submitted the first Actin and FAD2-1 gene sequences of Jatropha cinerea to GenBank at NCBI with the accession numbers MF363000 and MF363001, respectively, which provided important information for further studies in this area.

\section{CONCLUSION}

The present study is the first one on providing results about the expression of linoleic and oleic acids synthesis genes in Jatropha cinerea. The high expression of the KASII and FAD2-1 genes in mature seeds of $J$. cinerea and $J$. curcas suggests that the synthesis of linoleic acid is favored over the synthesis of oleic acid. Finally, the sequences of Jatropha cinerea submitted to the GenBank provide basic information to develop other studies to extent the knowledge and to comprehend the function, expression pattern and variability of genes involved not only in the synthesis of oleic and linoleic acids that will allow in a future to improve the content of oleic acid for species such as Jatropha cinerea that lives in harsh environments as the Sonoran Desert, characterized with high temperatures and saline soils but also to study the genes such as FAD2 in Jatropha cinerea, that is suggested to play a role in the resistance to abiotic stress such as salinity and cold in other plant species.

Table 1 - Jatropha curcas sequences which showed homology with Jatropha cinerea sequences obtained in this study.

\begin{tabular}{lcccc}
\hline Gene name & GenBank ID & Description & -Sequence identity (\%)- \\
\hline ACP1 & JQ806272.1 & Jatropha curcas plastid acyl carrier protein 1 mRNA & J. curcas & A. thaliana \\
KASII & NM_001306021.1 & Jatropha curcas 3-oxoacyl-[acyl-carrier-protein] synthase II, & 94 & 46 \\
chloeoplastic (LOC105638018), mRNA & 99 & 31 \\
D9SD & JQ806303.1 & Jatropha curcas delta-9-estearoyl-acyl carrier protein desaturase mRNA & 98 & 39 \\
FAD2-1 & JQ806297.1 & Jatropha curcas fatty acid desaturase 2 mRNA & 97 & 30 \\
FAD2-2 & JQ806301.1 & Jatropha curcas delta-12-acyl-lipid desaturase mRNA & 98 & 32 \\
Actin & NM_001308728.1 & Jatropha curcas actin-7 (LOC105645143), mRNA & 34 & 97 \\
\hline
\end{tabular}

Ciência Rural, v.48, n.11, 2018. 


\section{ACKNOWLEDGMENTS}

This work was supported by PROMEP (DSA/10.5/14/7061- Secretariat of Public Education-Mexico). The authors would like to thank Fernando Hernández-Godínez, Claudia Celeste Molina-Domínguez, Carlos Alonso Ballesteros-Córdova and Adán Valenzuela-Castillo for their technical assistance. JPL-F thanks CONACYT (Consejo Nacional de Ciencia y Tecnología), fellowship No. 549662.

\section{DECLARATION OF CONFLICTING} INTERESTS

The authors declared no potential conflicts of interest with respect to the research, authorship and/or publication of this article.

\section{AUTHORS' CONTRIBUTIONS}

JPL-F, LAM-J and CH-K conceived and designed experiments. JPL-F performed the experiments, JPL-F, LAM-J, NG$\mathrm{M}, \mathrm{OM}, \mathrm{MH}-\mathrm{O}$ and $\mathrm{CH}-\mathrm{K}$ carried out the lab analyses. LAM-J and CH-K supervised and coordinated the experiments. JPL-F, OM and MH-O performed statistical analyses of experimental data. JPL-F, MH-O and CH-K prepared the draft of the manuscript. All authors critically revised the manuscript and approved of the final version.

\section{REFERENCES}

BRITTAINE, R.; LUTALADIO, N. Jatropha: a smallholder bioenergy crop: the potential for pro-poor development. Rome: Food and Agriculture Organization of the United Nations (FAO), 2010. 29p. Available from: <http://www.fao.org/docrep/012/ i1219e/i1219e.pdf $>$. Accessed: Sept. 22, 2018.

FOFANA, B. et al. Gene expression of stearoyl-ACP desaturase and $\Delta 12$ fatty acid desaturase 2 is modulated during seed development of flax (Linum usitatissimum). Lipids, v.41, n.7, p.705-712, 2006. Available from: <https://onlinelibrary.wiley.com/doi/abs/10.1007/ s11745-006-5021-x>. Accessed: Setp. 22, 2018. doi: 10.1007/ s11745-006-5021-x.

FRESNEDO-RAMÍREZ, J.; OROZCO-RAMÍREZ, Q. Diversity and distribution of genus Jatropha in Mexico. Genetic Resources and Crop Evolution, v.60, n.3, p.1087-1104, 2013. Available from: $<$ https://link.springer.com/article/10.1007\%2Fs10722-012-9906-7>. Accessed: Sept. 22, 2018. doi: 10.1007/s10722-012-9906-7.

GÁMEZ-MEZA, N. et al. Chemical characterisation of kernels, kernel meals and oils from Jatropha cordata and Jatropha cardiophylla seeds. Journal of the Science of Food Agriculture, v.93, n.7, p.1706-1710, 2013. Available from: <https:// onlinelibrary.wiley.com/doi/abs/10.1002/jsfa.5955>. Accessed: Sept. 23, 2018. doi: 10.1002/jsfa.5955.

$\mathrm{GU}, \mathrm{K}$. et al. Expression of fatty acid and lipid biosynthetic genes in developing endosperm of Jatropha curcas. Biotechnology for Biofuels, v.5, n.1, p.47, 2012. Available from: < https://biotechnologyforbiofuels. biomedcentral.com/articles/10.1186/1754-6834-5-47>. Accessed: Sept. 22, 2018. doi: 10.1186/1754-6834-5-47.

HERNÁNDEZ, A. et al. Análisis del RNA: Estudio de la expresión génica. Nefrología, v.14, n.2, p.145-162,1994. Available from:
$<$ http://www.revistanefrologia.com/espublication-nefrologiaarticulo-analisis-del-rna-estudio-expresion-X0211699594006120>. Accessed: Sept. 23, 2018.

HISHIDA, M. et al, Antioxidant Enzyme Responses to Salinity Stress of Jatropha curcas and J. cinerea at Seedling Stage. Russian Journal of Plant Physiology, v.61, n.1, p.53-62, 2014. Available from:<https:// link.springer.com/article/10.1134\%2FS1021443714010063>. Accessed: Sept. 22, 2018. doi: 10.1134/S1021443714010063.

KHALIL, H. A., et al., A Jatropha biomass as renewable materials for biocomposites and its applications. Renewable and Sustainable Energy Reviews, v. 22, p. 667-685, 2013. Available from: <https://www.sciencedirect.com/science/article/ pii/S1364032112007393?via\%3Dihub>. Accessed: Sept. 23, 2018. doi: 10.1016/j.rser.2012.12.036.

LI, M.J. et al., Characterization of Five Putative Acyl Carrier Protein (ACP) Isoforms from Developing Seeds of Arachis hypogaea L. Plant Molecular Biology Reporter, v. 28 n.3, p. 365-372, 2010. Available from: <https://link.springer.com/ article/10.1007\%2Fs11105-009-0160-x>. Accessed: Sept. 22, 2018. doi: $10.1007 / \mathrm{s} 11105-009-0160-\mathrm{x}$.

LOVIO-FRAGOSO, J.P. et al., Physical characteristics and chemical constituents of Jatropha cinerea seeds. Rivista Italiana delle Sostanze Grasse, v.94, n.3, 2017. Available from: <http://www.innovhubssi. it/c/document_library/get_file?uuid=b494c5c7-85da-44c7-af6f6561238ac526\&groupId=11654>. Accessed: Sept. 23, 2018.

MA, Y. et al. Lipid Biosynthesis and Regulation in Jatropha, an Emerging Model for Woody Energy Plants. In: TSUCHIMOTO, S. The Jatropha Genome. Springer, 2017. Chap. 7 p.113127. Available from: <https://link.springer.com/chapter/10.10 07\%2F978-3-319-49653-5 7>. Accessed: Sept. 22, 2018. doi: $10.1007 \%$ FF978-3-319-49653-5_7.

MARTINEZ-HERRERA J. et al. Agroclimatic conditions, chemical and nutritional characterization of different provenances of Jatropha curcas L. from Mexico. European Journal of Scientific Research, v.39, p.396 - 407, 2010. Available from: $<$ http://repositoriodigital.inp.mx/handle/123456789/8636>. Accessed: Sept. 23, 2018.

OLIVEIRA, V.D. et al. Genetic variability in physic nuts cultivated in Northeastern Brazil. Ciência Rural, v.43, n.6, p. 978-984, 2013. Available from: $<$ http://www.scielo.br/scielo.php?script $=$ sci_ arttext\&pid=S0103-84782013000600006\&lng=en\&tlng=en>. Accessed: Sept. 22, 2018.

QU, J. et al. Development of marker-free transgenic Jatropha plants with increased levels of seed oleic acid. Biotechnology for Biofuels, v.5,n.1,p.10,2012.Availablefrom: $<$ https://biotechnologyforbiofuels. biomedcentral.com/articles/10.1186/1754-6834-5-10>. Accessed: Sept. 23, 2018.

RUUSKA, S.A. et al. Contrapuntal networks of gene expression during Arabidopsis seed filling. The Plant Cell, v.14, n.6, p.1191-1206, 2002. Available from: <http:/www.plantcell.org/ content/14/6/1191>. Accessed: Sept. 22, 2018. doi: 10.1105/ tpc. 000877 .

SCHERDER, C.; FEHR, W. Agronomic and seed characteristics of soybean lines with increased oleate content. Crop Science, v.48, p.1755-1758, 2008. Available from: $<$ https://dl.sciencesocieties.org/ publications/cs/abstracts/48/5/1755>. Accessed: Sept. 23, 2018. 
SOSA-SEGURA, M.P. et. al. Physical and Chemical Characterization of Three Non- Toxic Oilseeds from the Jatropha Genus. Journal of Food and Nutrition Research, v.2, n.1, p.5661, 2014. Available from: <http://pubs.sciepub.com/jfnr/2/1/10/ index.html $>$. Accessed: Sept. 22, 2018.

SOTO-LEÓN, S. et al. Jatropha cinerea seed oil as potencial nonconventional feedstock for biodiesel produced by an ultrasonic process. Revista Mexicana de Ingeniería Química, v.13, n.3, p.739-747, 2014. Available from: <http://www.scielo.org.mx/pdf/ rmiq/v13n3a8.pdf>. Accessed: Sept. 23, 2018.

TURNER, R. et al. Sonoran Desert Plants: An Ecological Atlas. United States of America: The University of Arizona Press, 2005. 246p. Available from: <http://www.bioone.org/ doi/abs/10.2985/0007-9367\%282007\%2979\%5B278b\%3AS DPAEA\%5D2.0.CO\%3B2>. Accessed: Sept. 22, 2018. doi: 10.2985/0007-9367(2007)79[278b:SDPAEA]2.0.CO;2.

WANG, R. et al. Production and selected fuel properties of biodiesel from promising non-edible oils: Euphorbia lathyris L., Sapium sebiferum L. and Jatropha curcas L. Bioresource technology, v. 102 n. 2, p. 1194-1199, 2011. Available from: $<$ https://www.sciencedirect. com/science/article/pii/S0960852410015798?via\%3Dihub>. Accessed: Sept. 23, 2018. doi: 10.1016/j.biortech.2010.09.066.

WEI, Q. et al. Cloning and characterization of a $\beta$-ketoacyl-acyl carrier protein synthase II from Jatropha curcas. Journal of Plant Physiology, v.169, n.8, p.816-824, 2012. Available from: $<$ https://www.sciencedirect. com/science/article/pii/S0176161712000958?via\%3Dihub>. Accessed: Sept. 22, 2018.

YE, J. et al. Improvement of J. curcas oil by genetic transformation. In: BAHADUR, B. et al. Jatropha, Challenges for a New Energy Crop. New York: Springer, 2013. Chap. 29. p. 547-562. Available from: <https://link.springer.com/chapter/10.1007\% 2F978-1-4614-4915-7 29>. Accessed: Sept. 23, 2018.

ZHANG, J. et al. Arabidopsis Fatty Acid Desaturase FAD2 Is Required for Salt Tolerance during Seed Germination and Early Seedling Growth. PLoS ONE, v.7, n.1, p. e30355, 2012. Available from: $<$ https://journals.plos.org/plosone/article?id=10.1371/journal. pone.0030355>. Accessed: Sept. 22, 2018. doi: 10.1371/journal. pone. 0030355 . 